\title{
Identifikasi Ukuran Tubuh Sapi Bali dan Simbal (Simmental-Bali) di Kecamatan Luhak Nan Duo Kabupaten Pasaman Barat
}

\author{
(Identification of Bali and Simbal Body Size in Luhak Nan Duo District, West Pasaman \\ District)
}

\section{F. L. Syaiful, Khasrad dan S. Maulida}

Fakultas Peternakan Universitas Andalas

Corresponding email : ferrylismanto@ansci.unand.ac.id

\begin{abstract}
The purpose of this study was to determine the body size identification of Bali and Cymbals (Simmental-Bali) in Luhak Nan Duo District, West Pasaman Regency. The method used in this research is a survey method of direct observation conducted randomly. Samples were taken as many as 60 bulls, namely Bali and Simbal cattle divided into 30 Bali cows and 30 Cymbal (Simmental-Bali) cows, each consisting of 10 cows with livestock age from weaning (I0), $1.5-2$ years (I1) and 2.5-3 years (I2). The data obtained were analyzed descriptively. While the ratio of body measurements and body weight to age and type of cattle were analyzed by t-test. The results showed that the average length of male Bali cattle in I0, I1, and I2 were as follows: $67.7 \pm 1.34 ; 82.3 \pm 7.01$; $112.8 \pm 2.57 \mathrm{~cm}$. Shoulder height: $84.5 \pm 1.58 ; 92.3 \pm 4.83 ; 111.9 \pm 4.28 \mathrm{~cm}$. Chest circumference, namely: 93.1 $\pm 2.23 ; 120.7 \pm 7.36 ; 142.4 \pm 7.73 \mathrm{~cm}$. While bodyweight was $53.09 \pm 3.36 ; 108.69 \pm 13.98 ; 209.35 \pm 24.04 \mathrm{~kg}$. The body length of the Cymbal cow is: $82 \pm 2.62 ; 106.4 \pm 0.97 ; 126.6 \pm 1.07 \mathrm{~cm}$. Shoulder height: $91.3 \pm 1.34$ $\mathrm{cm}, 105.3 \pm 0.95 \mathrm{~cm}$ and $123.7 \pm 2.31 \mathrm{~cm}$. Chest circumference, namely: $96.9 \pm 1.37 ; 136.7 \pm 1.49 ; 155.3 \pm 1.64$ $\mathrm{cm}$. While bodyweight $69.69 \pm 3.08 ; 179.93 \pm 5.01 ; 276.29 \pm 7.12 \mathrm{~kg}$. From the results of the study, it can be concluded that the body measurements of Cymbal (Simmental-Bali) cattle are superior to Bali cows in Luhak Nan Duo District, West Pasaman Regency.
\end{abstract}

Keywords: body size, Bali cattle, cymbal cattle, West Pasaman, West Sumatra

\begin{abstract}
ABSTRAK
Penelitian ini bertujuan untuk mengidentifikasi ukuran tubuh sapi Bali dan Simbal di daerah Luhak Nan Duo, Pasaman Barat. Metode penelitian menggunakan metode survei dengan menggunakan sampel sebanyak 60 ekor sapi jantan pada sapi Bali dan Simbal yang terbagi atas 30 ekor sapi Bali dan 30 ekor sapi Simbal. Setiap unit perlakuan terdiri atas 10 ekor. Perlakuan dikelompokkan pada berbagai umur ternak yakni lepas sapih (I0), 1,5-2 tahun (I1) dan 2,5-3 tahun (I2). Data yang diperoleh dianalisis secara deskriptif. Sedangkan perbandingan jenis sapi perlakuan dianalisis menggunakan uji-t. Dari hasil penelitian menunjukkan bahwa panjang badan sapi Bali jantan pada umur I0, I1, I2 yaitu: $67,7+1,34 ; 82,3 \pm 7,01 ; 112,8 \pm 2,57 \mathrm{~cm}$. Tinggi pundak: $84,5 \pm 1,58 ; 92,3 \pm 4,83$; $111,9 \pm 4,28 \mathrm{~cm}$. Lingkar dada yaitu: $93,1 \pm 2,23 ; 120,7 \pm 7,36 ; 142,4 \pm 7,73 \mathrm{~cm}$. Sedangkan bobot badan adalah $53,09 \pm 3,36 ; 108,69 \pm 13,98 ; 209,35 \pm 24,04 \mathrm{~kg}$. Panjang badan sapi Simbal yaitu: 82 $\pm 2,62 ; 106,4 \pm 0,97$; $126,6 \pm 1,07 \mathrm{~cm}$. Tinggi pundak: $91,3 \pm 1,34 ; 105,3 \pm 95 ; 123,7 \pm 2,31 \mathrm{~cm}$. Lingkar dada sebesar 96,9 \pm 37 ; $136,7 \pm 1,49 ; 155,3 \pm 1,64 \mathrm{~cm}$. Sedangkan bobot badan $69,69 \pm 3,08 ; 179,93 \pm 5,01 ; 276,29 \pm 7,12 \mathrm{~kg}$. Dari hal diatas dapat ditarik simpulan bahwa ukuran tubuh sapi Simbal lebih unggul dibandingkan sapi Bali.
\end{abstract}

Kata Kunci: ukuran tubuh, sapi Bali, sapi Simbal, Pasaman Barat, Sumatera Barat

\section{PENDAHULUAN}

Sapi merupakan salah satu sumber kekayaan dan potensi sumber daya genetik Indonesia. Noor (2004), mengemukakan bahwa sapi asli Indonesia memiliki keunggulan terhadap adaptasi lingkungan dan iklim tropik. Ternak ini sangat cocok untuk dipelihara dan dikembangkan di Indonesia.

Menurut Martojo (2003) bahwa sapi bali merupakan salah satu plasma nutfah Indonesia yang diperoleh dari hasil domestifikasi dari Banteng liar. Sapi ini memiliki keunggulan spesifik yang perlu dilestarikan keberadaannya. Disamping itu, sapi Bali ini telah tercatat dalam FAO sebagai aset dunia yang merupakan salah salah satu bangsa-bangsa sapi yang terdapat di dunia (DGLS, 2003).

Pada tahun 2017, Indonesia memiliki populasi potong sebesar 16.599.247 ekor sedangkan pada tahun 2012 populasi sapi potong sebesar 15.980.696 ekor. Dari data ini selama 5 
tahun terakhir terjadi peningkatan populasi sapi sebesar 3,87\%. Sedangkan di Sumatera Barat, pada tahun 2017 populasi sapi potong adalah sebesar 413.124 ekor, lalu pada tahun 2012 populasi sapi potong sebesar 359.233 ekor. Selama 5 tahun terakhir terjadi peningkatan populasi sapi sebesar 15\% (BPS, 2017).

Kabupaten Pasaman Barat merupakan salah satu lumbung sumber bibit ternak sapi Bali/sapi potong di Sumatera Barat, yang sangat potensial untuk pengembangan ternak sapi yang didukung dengan luasnya perkebunan sawit mencapai 102.200 Ha. Pengembangan ternak sapi ini di dukung oleh potensi sumber daya pakan yang melimpah. Pada daerah ini terdapat populasi sapi mencapai 19.277 ekor/tahun. Disamping itu pada daerah ini juga terdapat di Kecamatan Luhak Nan Duo yaitu salah satu nagarinya adalah Koto Baru dengan jumlah populasi sebesar 3.647 ekor (Dinas Tanaman Pangan Hortikultura dan Peternakan Pasaman Barat, 2018); (BPS Pasaman Barat, 2018).

Menurut Chamdi (2005) bahwa produktivitas merupakan suatu kemampuan produksi seekor ternak (bobot badan).

Kecepatan pertumbuhan tubuh ternak bisa diketahui berdasarkan pola pertumbuhan dari setiap dimensi tubuh. Ditambahkan oleh Rianto dan Endang (2011) bahwa penampilan sapi jantan yang baik dapat diukur dengan pengukuran dimensi tubuhnya berupa pengukuran bobot badan, tinggi pundak, panjang badan dan lingkar dada. Pertambahan umur ternak maka semakin meningkat pula ukuran tubuh dan bobot tubuh ternak (Ismirandy, 2018).

Menurut Sariubang et al. (1998) menyatakan bahwa belakangan ini terjadi penurunan genetik sapi Bali beserta turunnya berat badan dan ukuran-ukuran tubuh ternak sapi. Hal ini disebabkan oleh turunnya mutu genetik sapi Bali adalah seleksi genetik dan inbreeding. Untuk meningkatkan produktivitas sapi Bali sebagian besar peternak melakukan kawin silang atau memasukkan darah baru melalui program IB (Inseminasi Buatan) menggunakan semen beku, diantaranya persilangan sapi Bali dengan Simmental (Simbal). Namun saat ini, belum adanya teridentifikasi data ukuran-ukuran tubuh sapi Bali dan Simbal untuk peningkatan produktivitas ternak atau produksi daging.

Untuk itu, perlu dilakukan penelitian pada ukuran-ukuran tubuh sapi Bali dan Simbal dalam upaya pengembangan sapi Bali di masa mendatang. Penelitian ini bertujuan untuk mengidentifikasi data ukuran-ukuran tubuh sapi
Bali dan Simbal pada daerah Luhak Nan Duo Kabupaten Pasaman Barat.

\section{MATERI DAN METODE}

Penelitian ini menggunakan sapi Bali dan Simbal (Simmental-Bali) sebanyak 60 ekor yang berjenis kelamin jantan. Adapun penggunaan sapi dalam perlakuan terdiri dari sapi Bali dan sapi Simbal (Simmental-Bali) yaitu: lepas sapih $\left(\mathrm{I}_{0}\right), 1,5-2$ tahun $\left(\mathrm{I}_{1}\right)$ dan 2,5-3 tahun $\left(\mathrm{I}_{2}\right)$ terbagi atas 30 ekor untuk sapi Bali dan 30 ekor sapi Simbal (Simmental-Bali) yang masing-masing terdiri atas 10 ekor. Sedangkan alat yang digunakan pada penelitian ini adalah tongkat ukur dari stainless steel, pita ukur, alat tulis, laptop dan kamera.

\section{Metode Penelitian}

Penelitian ini dilakukan menggunakan metode observsi atau survei. Data yang dikumpulkan bersifat primer. Pengambilan sampel berdasarkan purposive sampling termasuk kriteria inklusi antara lain jenis sapi yang memiliki ciri-ciri dari sapi Bali dan Simbal (Simmental-Bali), serta umur ternak dari lepas sapih $\left(\mathrm{I}_{0}\right), \mathrm{I}_{1}$ dan $\mathrm{I}_{2}$. Sedangkan pengamatan dilakukan secara acak terhadap ternak yang terdapat di Kecamatan Luhak Nan Duo Kabupaten Pasaman Barat.

\section{Variabel Yang Diamati}

Ukuran-ukuran tubuh yang diamati pada penelitian ini adalah panjang badan, tinggi pundak, lingkar dada dan bobot badan yang pengukurannya sesuai Awaluddin dan Panjaitan (2010) dan pendugaan umur berdasarkan gigi meliputi:

1. Panjang badan, diukur dengan membentangkan tongkat ukur dari siku (Humerus) sampai benjolan yang terdapat pada tulang tapis (Tuber ischii) $(\mathrm{cm})$.

2. Tinggi Pundak, jarak dari permukaan yang rata sampai bagian tertinggi pundak melewati bagian scapula secara tegak lurus, sedangkan alat ukur yang digunakan adalah tongkat ukur $(\mathrm{cm})$.

3. Lingkar Dada, pengukuran dilakukan dengan pita ukur $(\mathrm{cm})$ pada sekeliling rongga dada yang terdapat pada belakang punuk dan dibelakang sendi bahu (Os scapula). 
4. Bobot Badan, diprediksi menggunakan metode Djagra.

\section{Analisis Data}

Data hasil penelitian dianalisis secara deskriptif, melalui perhitungan nilai rataan (x) dan simpangan baku (s) (Stell dan Torrie, 1995). Sedangkan perbandingan ukuran-ukuran tubuh pada bangsa sapi berbeda dianalisis menggunakan uji-t.

\section{HASIL DAN PEMBAHASAN}

Ukuran-ukuran tubuh sapi Bali dan Simbal (Simmental-Bali) jantan pada tingkat umur lepas sapih $\left(\mathrm{I}_{0}\right), 1,5-2$ tahun $\left(\mathrm{I}_{1}\right)$ dan 2,5-3 tahun $\left(\mathrm{I}_{2}\right)$ pada daerah Luhak Nan Duo Kabupaten Pasaman Barat terlihat pada Tabel 1 dan 3.

\section{Panjang Badan}

Pada hasil penelitian yang diperoleh menunjukkan bahwa panjang badan sapi Bali dan Simbal (Simmental-Bali) jantan pada lepas sapih $\left(\mathrm{I}_{0}\right)$ terlihat pada Tabel 1. Adapun ukuran panjang badan sapi Bali dan Simbal (SimmentalBali) adalah sebagai berikut: $67,7 \pm 1,34$ dan $82 \pm 2,62 \mathrm{~cm}$. Pada berumur $1,5-2$ tahun $\left(\mathrm{I}_{1}\right)$ yaitu: $82,3 \pm 7,01$ dan $106,4 \pm 0,97 \mathrm{~cm})$. Sedangkan pada umur 2,5-3 tahun $\left(\mathrm{I}_{2}\right)$ yaitu; 112,8 $\pm 2,57$ dan $126,6 \pm 1,07 \quad \mathrm{~cm}$. Dari analisis statistik menunjukkan bahwa perbandingan panjang badan antara sapi Bali dan Simbal (SimmentalBali) jantan pada lepas sapih $\left(\mathrm{I}_{0}\right), 1,5-2$ tahun $\left(\mathrm{I}_{1}\right)$ dan umur 2,5-3 tahun $\left(\mathrm{I}_{2}\right)$ terdapat perbedaan sangat nyata $(\mathrm{P}<0,01)$.

Terlihat dari hasil penelitian bahwa sapi

Simbal (Simmental-Bali) menunjukkan penampilan panjang badan lebih baik dari sapi Bali. Hal ini disebabkan adanya perbedaan faktor genetik dan manajemen pemeliharaan terhadap kedua jenis sapi, dimana faktor genetik pada sapi Bali yang mengalami penurunan sedangkan sapi Simbal (Simmental-Bali) sudah mengalami perbaikan mutu genetik yang lebih baik. Disamping itu sapi Simbal (Simmental-Bali) memiliki pertumbuhan yang lebih cepat dibandingkan sapi Bali, sehingga terdapat perbedaan pada ukuran panjang badannya.

Thalib dan Siregar (1999) mengemukakan bahwa performan sapi persilangan lebih unggul dari sapi lokal. Di samping itu sapi persilangan memiliki pertumbuhan yang cepat dan kualitas karkas yang baik, sapi hasil silangan juga mempunyai harga jual yang tinggi. Dilanjutkan Tazkia (2008) mengemukakan bahwa sapi berumur 1-8 bulan digolongkan pedet, umur pedet pertumbuhan mulai memasuki fase percepatan. Pada fase percepatan ini pertumbuhan sapi akan maksimal bila ditunjang dengan nutrisi yang baik, tatalaksana dan lingkungan. Menurut Rusfidra (2006) bahwa potensi persilangan antar populasi yang berbeda bangsa akan nampak secara visual pada turunan persilangan nya, ternak yang dikawinkan berbeda bangsa akan mewariskan turunan fenotipe pada hasil persilangan nya.

Tabel 1. Rataan Ukuran-ukuran Tubuh Sapi Bali Jantan dan Simbal (Simmental-Bali) Jantan di Kecamatan Luhak Nan Duo Kabupaten Pasaman Barat.

\begin{tabular}{clccccc}
\hline \multirow{2}{*}{ No } & \multirow{2}{*}{ Bangsa Sapi } & Klasifikasi & \multirow{2}{*}{ Umur } & & \multicolumn{3}{c}{ Ukuran-ukuran Tubuh Sapi $(\mathrm{cm})$} \\
\cline { 5 - 7 } & & & PB & TP & LD \\
\hline 1. & Sapi Bali & \multirow{2}{*}{ Lepas sapih $\left(\mathrm{I}_{0}\right)$} & 10 & $67,7 \pm 1,34^{\mathrm{a}}$ & $84,5 \pm 1,58^{\mathrm{a}}$ & $93,1 \pm 2,23^{\mathrm{a}}$ \\
& Sapi Simbal & 10 & $82 \pm 2,62^{\mathrm{b}}$ & $91,3 \pm 1,34^{\mathrm{b}}$ & $96,9 \pm 1,37^{\mathrm{b}}$ \\
\hline 2. & Sapi Bali & \multirow{2}{*}{$1,5-2$ tahun $\left(\mathrm{I}_{1}\right)$} & 10 & $82,3 \pm 7,01^{\mathrm{a}}$ & $92,3 \pm 4,83^{\mathrm{a}}$ & $120,7 \pm 7,36^{\mathrm{a}}$ \\
& Sapi Simbal & & 10 & $106,4 \pm 0,97^{\mathrm{b}}$ & $105,3 \pm 0,95^{\mathrm{b}}$ & $136,7 \pm 1,49^{\mathrm{b}}$ \\
\hline 3. & Sapi Bali & \multirow{2}{*}{$2,5-3$ tahun $\left(\mathrm{I}_{2}\right)$} & 10 & $112,8 \pm 2,57^{\mathrm{a}}$ & $111,9 \pm 4,28^{\mathrm{a}}$ & $142,4 \pm 7,73^{\mathrm{a}}$ \\
& Sapi Simbal & 10 & $126,6 \pm 1,07^{\mathrm{b}}$ & $123,7 \pm 2,31^{\mathrm{b}}$ & $155,3 \pm 1,64^{\mathrm{b}}$ \\
\hline & & & & & \\
\hline
\end{tabular}

Keterangan:

- Angka superskrip berbeda pada kolom sama menunjukkan perbedaan sangat nyata $(\mathrm{P}<0,01)$.

- Superskrip yang berbeda pada kolom yang sama menunjukkan perbedaan yang sangat nyata $(\mathrm{P}<0,01)$.

- $\mathrm{PB}=$ Panjang Badan

- $\quad \mathrm{TP}=$ Tinggi Pundak

- $\quad \mathrm{LD}=$ Lingkar Dada

- $\mathrm{N}=$ Jumlah sapi perlakuan 
Pada Tabel 1. terlihat bahwa rataan panjang badan sapi Bali dan Simbal (SimmentalBali) jantan berumur 1,5-2 tahun $\left(\mathrm{I}_{1}\right)$ yaitu: $82,3 \pm 7,01$ dan $106,4 \pm 0,97 \mathrm{~cm})$. Pada hasil penelitian ini menunjukkan penampilan dari panjang badan lebih baik dibanding sapi Bali. Hal ini disebabkan adanya perbedaan faktor genetik dan manajemen pemeliharaan terhadap kedua jenis sapi, dimana faktor genetik pada sapi Bali yang mengalami penurunan sedangkan sapi Simbal (Simmental-Bali) sudah mengalami perbaikan mutu genetik yang lebih baik. Di samping itu sapi Simbal (Simmental-Bali) memiliki pertumbuhan yang lebih cepat dibandingkan sapi Bali, sehingga terdapat perbedaan pada ukuran panjang badannya.

Sugeng (2003) mengemukakan bahwa faktor-faktor yang mempengaruhi ukuran tubuh sapi ternak yaitu bangsa, jenis kelamin, umur, pakan, suhu dan iklim. Dilihat secara visual sapi Bali dan Simbal (Simmental-Bali) berbeda, hal ini sesuai dengan pernyataan Subandriyo dan Anggraini (1996) yang menyatakan bahwa sapi hasil persilangan memiliki performan lebih unggul dari sapi tetua.

Sedangkan hasil rataan panjang badan sapi Bali dan Simbal (Simmental-Bali) jantan berumur 2,5-3 tahun $\left(\mathrm{I}_{2}\right)$ yaitu; $112,8 \pm 2,57$ dan $126,6 \pm 1,07 \mathrm{~cm}$ (Tabel 1). Dari hasil penelitian menunjukkan bahwa sapi Simbal (SimmentalBali) pada penelitian ini menunjukkan penampilan panjang badan lebih baik dari sapi Bali. Hal ini sesuai dengan penelitian Susanti et al (2015), pertumbuhan sapi hasil persilangan akan dipengaruhi oleh pejantan yang digunakan dalam perkawinan/inseminasi ternak.

Sapi persilangan memiliki performans lebih unggul dibandingkan sapi lokal, sehingga banyak perternak menyilangkan sapi lokal dengan sapi simental dan Limousin (Thalib dan Siregar, 1999). Pertumbuhan sapi persilangan memiliki pertumbuhan yang lebih cepat dan kualitas karkas yang dihasilkan lebih baik. Disamping itu dari harga jual sapi persilangan memiliki harga jual yang lebih tinggi.

\section{Tinggi Pundak}

Hasil penelitian yang diperoleh menunjukkan bahwa tinggi pundak pada sapi Bali dan Simbal jantan lepas sapih (I0) yaitu $84,5 \pm 1,58$ dan $91,3 \pm 1,34 \mathrm{~cm}$. Sedangkan pada umur 1,5-2 tahun (I1) sebesar 92,3 $\pm 4,83$ dan $105,3 \pm 0,95 \mathrm{~cm}$. Pada umur 2,5-3 tahun (I2) yaitu: $111,9 \pm 4,28$ dan $123,7 \pm 2,31 \mathrm{~cm}$ (Tabel. 1). Dari analisis statistik menunjukkan bahwa ukuran tinggi pundak sapi Bali dan Simbal (Simmental-Bali) terdapat perbedaan sangat nyata $(\mathrm{P}<0,01)$. Penampilan tinggi pundak Sapi Simbal lebih baik dari sapi Bali. Hal ini disebabkan oleh perbedaan faktor genetik dan manajemen pemeliharaan terhadap kedua jenis sapi, dimana faktor genetik pada sapi Bali yang mengalami penurunan sedangkan sapi Simbal sudah mengalami perbaikan mutu genetik yang lebih baik. Sapi Simbal juga memiliki pertumbuhan yang lebih cepat dibandingkan sapi Bali, sehingga terdapat perbedaan pada ukuran tinggi pundaknya.

Sugeng (2003) mengemukakan bahwa faktor-faktor yang mempengaruhi ukuran tubuh sapi ternak yaitu bangsa, jenis kelamin, umur, pakan, suhu dan iklim. Subandryo dan Anggraini (1996), sapi persilangan memiliki performans lebih unggul dari bangsa tetuanya. Menurut Sampurna et al., (2013) bahwa pertumbuhan tinggi punuk pedet sapi jantan dan betina pada umur $0-6$ bulan mengalami pertumbuhan yang lebih cepat dari pada pinggulnya. Hal ini disebabkan kaki bagian depan lebih aktif bergerak pada saat pedet menyusu pada induknya. Perbedaan tuntutan fisiologis dan fungsional yang berbeda berakibat pula perbedaan urutan pertumbuhan.

Dari hasil penelitian, rataan tinggi pundak sapi Bali dan Simbal (Simmental-Bali) jantan umur 1,5-2 tahun $\left(I_{1}\right)$ sebesar 92,3 $\pm 4,83$ dan 105,3 $\pm 0,95 \mathrm{~cm}$ (Tabel 1). Sapi Simbal menunjukkan penampilan tinggi pundak lebih baik dari sapi Bali. Hal ini disebabkan oleh perbedaan faktor genetik, dimana sapi Simbal memiliki pertumbuhan yang lebih cepat dibandingkan sapi Bali sehingga terdapat perbedaan pada ukuran tinggi pundaknya.

Thalib dan Siregar (1999) menyatakan bahwa sapi hasil persilangan memiliki perfomans yang lebih baik dibandingkan dengan sapi lokal. Puncak pertumbuhan sapi yaitu pada usia 2 tahun, setelah itu maka pertumbuhan sapi akan menurun. Hal ini sesuai dengan Rahayu (2003) bahwa pertumbuhan sapi akan menurun setelah ternak berusia 2-2,5 tahun (dewasa tubuh), kemudian akan mengalami pertumbuhan tulang tetapi kecepatannya berkurang sampai pertumbuhan tulang berhenti. Ditambahkan oleh Sugeng (2003) bahwa ukuran tubuh ternak akan beragam, hal ini disebabkan oleh beberapa faktor yaitu bangsa, jenis kelamin sapi, umur sapi, pakan yang diberikan kepada ternak sapi dan suhu serta iklim lingkungan di sekitar habitat sapi. 
Dari hasil penelitian, rataan tinggi pundak sapi Bali dan Simbal (Simmental-Bali) jantan 2,5-3 tahun $\left(\mathrm{I}_{2}\right)$ sebesar 111,9 $\pm 4,28$ dan $123,7 \pm 2,31 \mathrm{~cm}$. Sapi Simbal (Simmental-Bali) pada penelitian ini menunjukkan penampilan tinggi pundak lebih baik dari sapi Bali. Hal ini disebabkan oleh ada perbedaan faktor genetik dan manajemen pemeliharaan. Menurut Sugeng (2003) bahwa ukuran tubuh berbeda yang dipengaruhi oleh bangsa ternak, jenis kelaminnya, umur sapi, pakan yang diberikan kepada ternak sapi dan suhu serta iklim lingkungan di sekitar habitat sapi. Dilihat secara visual sapi Bali dan Simbal (Simmental-Bali) berbeda, hal ini sesuai dengan Subandriyo dan Anggraini (1996) bahwa sapi persilangan memiliki performans lebih unggul dari induknya..

\section{Lingkar Dada}

Pada Tabel 1 dapat dilihat bahwa lingkar dada sapi Bali dan Simbal jantan lepas sapih $\left(\mathrm{I}_{0}\right)$ sebesar: 93,1 $\pm 2,23$ dan 96,9 $11,37 \mathrm{~cm}$. sapi Simbal memiliki pertumbuhan yang lebih cepat di bandingkan sapi Bali, sehingga terdapat perbedaan pada ukuran lingkar dadanya. Hal ini disebabkan oleh dimana faktor genetik pada sapi Bali yang mengalami penurunan sedangkan sapi Simbal (Simmental-Bali) sudah mengalami perbaikan mutu genetik yang lebih baik.

Menurut Subandriyo dan Anggraini (1996) yang menyatakan bahwa hasil persilangan umumnya mempunyai penampilan yang lebih baik dibandingkan dengan bangsa tetua nya. Sugeng (2003) mengungkapkan bahwa adanya perbedaan ukuran tubuh suatu ternak dipengaruhi oleh adanya beberapa faktor antara lain pengaruh bangsa sapi, jenis kelamin sapi, umur sapi, pakan yang diberikan kepada ternak sapi dan suhu serta iklim lingkungan di sekitar habitat sapi. Santoso (2008) bahwa lingkar dada dapat digunakan sebagai indikator kapasitas tubuh sapi, sebab semakin besar lingkar dada organ-organ yang terdapat di dalam rongga dada juga semakin besar seperti paru-paru dan jantung.

Dari hasil penelitian, lingkar dada sapi Bali dan Simbal jantan umur 1,5-2 tahun $\left(\mathrm{I}_{1}\right)$

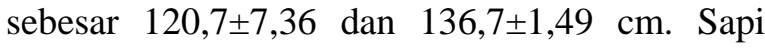
Simbal (Simmental-Bali) menunjukkan penampilan lingkar dada lebih baik dari sapi Bali. Di samping itu sapi Simbal (SimmentalBali) memiliki pertumbuhan yang lebih cepat dibandingkan sapi Bali, sehingga terdapat perbedaan pada ukuran lingkar dadanya. Rahayu
(2003) mengemukakan bahwa pertumbuhan tubuh ternaka akan terhenti setelah dewasa tubuh yang diperkirakan umur 2-2,5 tahun. Setelah dewasa tubuh maka kecepatan pertumbuhan akan menurun yang diikuti dengan pertumbuhan tulang sampai pertumbuhan tulang terhenti.

Hasil rataan lingkar dada sapi Bali dan Simbal jantan umur 2,5-3 tahun $\left(\mathrm{I}_{2}\right)$ adalah $142,4 \pm 7,73$ dan 155,3 $\pm 1,64 \mathrm{~cm}$. Sapi Simbal memiliki lingkar dada lebih baik dari sapi Bali. Sapi Simbal mempunyai pertumbuhan yang lebih cepat dibandingkan sapi Bali, sehingga terdapat perbedaan pada ukuran lingkar dadanya. Rusfidra (2006) yang menyatakan bahwa potensi persilangan antar populasi yang berbeda bangsa akan nampak secara visual pada turunan persilangan nya, ternak yang dikawinkan berbeda bangsa akan mewarisi turunan fenotipe pada hasil persilangan nya. Dimana besarnya lingkar dada pada sapi dipengaruhi oleh faktor genetik, lingkungan, pakan, manajemen dan jenis kelamin.

\section{Bobot Badan}

Bobot badan sapi Bali dan Simbal jantan terhadap klasifikasi umur terlihat pada Tabel 2.

Pada hasil penelitian yang diperoleh terlihat pada Tabel 2 menunjukkan bobot badan sapi Bali dan Simbal jantan lepas sapih $\left(\mathrm{I}_{0}\right)$ yaitu:

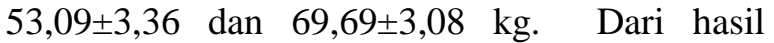
analisis statistik menunjukkan bahwa bobot badan sapi Bali dan Simbal terdapat perbedaan yang sangat nyata $(\mathrm{P}<0,01)$.

Sapi Simbal menunjukkan penampilan bobot badan lebih baik dari sapi Bali. Perbedaan ini dikarenakan oleh faktor genetik dan tata kelola ternak. Faktor genetik pada sapi Bali yang mengalami penurunan sedangkan sapi Simbal sudah mengalami perbaikan mutu genetik yang lebih baik.

Di samping itu sapi Simbal mempunyai pertumbuhan yang lebih cepat dibandingkan sapi Bali, sehingga terdapat perbedaan pada kenaikan bobot badannya.

Sapi Simbal menunjukkan penampilan bobot badan lebih baik dari sapi Bali. Hal ini disebabkan oleh perbedaan faktor genetik dan manajemen pemeliharaan. faktor genetik pada sapi Bali yang mengalami penurunan sedangkan sapi Simbal sudah mengalami perbaikan mutu genetik yang lebih baik. Di samping itu sapi Simbal mempunyai pertumbuhan yang lebih cepat dibandingkan sapi Bali, sehingga terdapat perbedaan pada kenaikan bobot badannya. 
Tabel 2. Rataan Bobot Badan Sapi Bali Jantan dan Simbal Jantan terhadap Klasifikasi Umur

\begin{tabular}{clccc}
\hline No & Bangsa Sapi & N & Klasifikasi Umur & Rataan Bobot Badan $(\mathrm{kg})$ \\
\hline 1. & Sapi Bali & 10 & Lepas sapih $\left(\mathrm{I}_{0}\right)$ & $53,09 \pm 3,36^{\mathrm{a}}$ \\
& Sapi Simbal & 10 & & $69,69 \pm 3,08^{\mathrm{b}}$ \\
2. & Sapi Bali & 10 & $1,5-2$ tahun $\left(\mathrm{I}_{1}\right)$ & $108,69 \pm 13,98^{\mathrm{a}}$ \\
& Sapi Simbal & 10 & & $179,93 \pm 5,01^{\mathrm{b}}$ \\
3. & Sapi Bali & 10 & $2,5-3$ tahun $\left(\mathrm{I}_{2}\right)$ & $209,35 \pm 24,04^{\mathrm{a}}$ \\
& Sapi Simbal & 10 & & $276,29 \pm 7,12^{\mathrm{b}}$ \\
& Total & 60 & & \\
\hline
\end{tabular}

Keterangan:

- Superskrip yang berbeda pada kolom yang sama menunjukkan perbedaan yang sangat nyata $(\mathrm{P}<0,01)$

- $\mathrm{N}=$ Jumlah sapi perlakuan

Sapi Simbal menunjukkan penampilan bobot badan lebih baik dari sapi Bali. Hal ini disebabkan oleh perbedaan faktor genetik dan manajemen pemeliharaan. Faktor genetik pada sapi Bali yang mengalami penurunan sedangkan sapi Simbal sudah mengalami perbaikan mutu genetik yang lebih baik. Di samping itu sapi Simbal mempunyai pertumbuhan yang lebih cepat dibandingkan sapi Bali, sehingga terdapat perbedaan pada kenaikan bobot badannya. Ditambahkan oleh Luthfi dan Affandhy (2013) mengemukakan bahwa perubahan ukuran tubuh akan dipengaruhi oleh pakan.

Pada Tabel 2 terlihat bahwa rataan bobot badan sapi Bali dan Simbal jantan umur 1,5-2

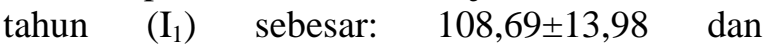
$179,93 \pm 5,01 \mathrm{~kg}$. Bobot badan Sapi Simbal lebih baik dari sapi Bali, hal ini disebabkan oleh persilangan. Depison dan Sumarsono (2001). Bobot badan serta pertambahan bobot badan ternak sapi hasil persilangan pejantan Simmental dengan Bali lebih baik dibandingkan pejantan Brahman, Limousin dan Bali. Sitorus et al (1995) mengatakan bahwa persilangan sapi Bali dengan bangsa subtropik akan menghasilkan bobot badan yang lebih tinggi dan peningkatan mutu genetik anaknya. Sehingga dapat dinyatakan persilangan sapi Simmental, Ongole, Brahman dan Limousin dengan induk sapi Bali dapat meningkatkan mutu genetik turunannya dan turunan terbaik adalah hasil perkawinan pejantan Simmental dan induk Bali. Ditambahkan oleh Dapison (2010), sapi hasil persilangan antara induk Bali dan pejantan Simental menghasilkan keturunan yang lebih unggul dibandingkan persilangan Limosin, Brahan dan PO baik dari segi bobot sapih dan ukuran tubuh ternak.

Pada hasil penelitian diperoleh rataan bobot badan sapi Bali dan Simbal jantan umur 2,5-3 tahun (I2) adalah 209,35 $\pm 24,04$ dan $276,29 \pm 7,12 \mathrm{~kg}$. Sapi Simbal memiliki bobot badan lebih unggul dibandingkan sapi Bali. Sapi Simbal (Simmental-Bali) juga memiliki pertumbuhan yang lebih cepat dibandingkan sapi Bali, sehingga terdapat perbedaan pada kenaikan bobot badannya. Hasil penelitin ini sesuai dengan pendapat Dapison dan Sumarsono (2011); Sitorus et al (1995) bahwa pertumbuhan bobot badan sapi Bali persilangan memiliki bobot badan yang lebih unggul. Pada ternak berumur diatas 3 tahun terjadi penimbunan lemak sehingga akan berpengaruh terhadap nilai jual ternak. Ditambahkan oleh Bambang (2005), pertumbuhan ternak sudah mencapai dewasa maka pertumbuhannya terhenti. Namun disaat ini terjadi perubahan dengan adanya penimbunan lemak.

\section{KESIMPULAN DAN SARAN}

Dari hasil penelitian dapat diambil kesimpulan bahwa ukuran-ukuran tubuh sapi Simbal (Simmental-Bali) pada daerah Luhak Nan Duo Kabupaten Pasaman Barat lebih unggul/besar dibandingkan sapi Bali.

\section{DAFTAR PUSTAKA}

Awaluddin dan Panjaitan, T. 2010. Petunjuk Praktis Pengukuran Ternak Sapi Potong. Balai Pengkajian Teknologi Pertanian, NTB.

Badan Pusat Statistik. 2017. Jumlah Populasi Sapi Potong di Indonesia. https://www.bps.go.id/link Table Dinamis/view/id/1016.

Badan Standarisasi Nasional (BSN). 2008. Standar Nasional Indonesia/ SNI 7355: 2008. Bibit Sapi Bali. 
Chamdi, A.N., 2005. Karakteristik Sumberdaya Genetik Ternak Sapi Bali (Bos-Bibos) dan Alternatif Pola Konservasinya. Biodiversitas. 6(1): 70-75.

Depison dan Sumarsono, T., 2001. Evaluasi hasil perkawinan induk sapi Bali dengan beberapa bangsa Pejantan di Kecamatan Rimbo Bujang Kabupaten Bungo Tebo. Jurnal Ilmiah Ilmu-ilmu Peternakan Fakultas Peternakan Universitas Jambi. IV(1): 29 - 35.

Dinas Tanaman Pangan Hortikultura dan Peternakan Pasaman Barat. 2018. Data Jumlah Populasi Ternak Sapi Potong di Kabupaten Pasaman Barat. Pasaman Barat

DGLS. 2003. National Report on Animal Genetic Resources Indonesia. Directorate Generale of Livestock Services (DGLS) Directorate of Livestock Breeding, Indonesia.

Depison. 2010. Performans Anak Hasil Persilangan Induk Sapi Bali dengan beberapa bangsa pejantan di Kabupaten Batanghari Provinsi Jambi. Agripet Vol 10, No. 1, April 2010

Ismirandy. A. 2018. Laju pertumbuhan dan ukuran tubuh sapi bali lepas sapih yang diberi pakan konsentrat pada kategori bobot badan yang berbeda. Skripsi. Jurusan Ilmu Peternakan Fakultas Sains dan Teknologi Universitas Islam Negeri Alauddin, Makassar

Luthfi, M dan Affandhy L. 2013. Pertambahan Bobot Badan Harian dan Skor Kondisi Tubuh Pedet Silangan Pra Sapih dengan Teknologi Creep Feeding di Peternakan Rakyat. Loka Penelitian Sapi Potong. Grati, Pasuruan, Jawa Timur.

Martojo H. 2003. Indigenous Bali Cattle: The Best Suited Cattle Breed for Sustainable Small Farms in Indonesia. Laboratory of Animal Breeding and Genetics, Faculty of Animal Science, Bogor Agricultural University, Indonesia.

Noor, R. R. 2004. Genetika Ternak. Penebar Swadaya, Jakarta.
Rahayu, B.S. T. 2003. Studi bobot badan dan ukuran-ukuran tubuh sapi Pesisir di Kabupaten Pesisir Selatan dan Padang Pariaman Sumatera Barat. Skripsi. Fakultas Peternakan Institut Pertanian Bogor, Bogor.

Rianto, E dan P. Endang. 2011. Sapi Potong. Cetakan 3. Swadaya, Jakarta.

Rusfidra A. 2006. Dasar Fisiologis Pewarisan Sifat. Bahan Ajar Dasar Pemuliaan Ternak. Fakultas Peternakan Universitas Andalas, Padang.

Sampurna, I.P., I.K. Saka, I.G. Oka , and P. Sentana. 2013. Biplot simulation of exponential function to determine body dimension's growth rate of Bali calf. Canadian Journal on Computing in Mathematics, Natural Scienses, Engineering and Medicine, IV(1) : 8792.

Santoso, G. 2008. Metodologi Penelitian Kuantitatif Dan Kualitatif. Prestasi Pustaka, Jakarta.

Sariubang, M., D. Pasambe, dan Chalidjah. 1998. Pengaruh kawin silang terhadap performans hasil turunan pertama (F1) pada sapi Bali di Sulawesi Selatan. Prosiding Seminar Nasional Peternakan dan Veteriner. Bogor, 1-2 Desember 1998.

Sitorus, P., Subandriyo, Prasetyo, L.H., Rachmawati, S., Tambing, S.N., Gunawan, A. dan Setiadi, B., 1995. Pengaruh Penyebaran Berbagai Jenis Sapi Bibit melalui Inseminasi Buatan terhadap Penyebaran dan Pengembangan Ternak Sapi di Kawasan Timur Indonesia. Pusat Penelitian dan Pengembangan Peternakan, Bogor.

Sugeng, Y.B. 2003. Sapi Potong. Penebar Swadaya, Jakarta.

Susanti, I., M. Nur Ihsan dan Sri Wahjuningsih. 2015. Pengaruh bangsa pejantan terhadap pertumbuhan pedet hasil IB di wilayah Kecamatan Bantur Kabupaten Malang. J. Ternak Tropika Vol. 16, No.1: 41-47, 2015 
Stell, R. G. D dan J. H. Torrie. 1995. Prinsip dan Prosedur Statistika. Gramedia Pustaka, Jakarta.

Tazkia, R. 2008. Pola dan Pendugaan Sifat Pertumbuhan Sapi Friesian-Holstein Betina Berdasarkan Ukuran Tubuh di KPSBU Lembang. Program studi
Teknologi Produksi Ternak. Fakultas Peternakan, Bogor.

Thalib, C. dan Siregar, A.R., 1999. Faktor-faktor yang Mempengaruhi Pertumbuhan Pedet PO dan Crosbrednya dengan Bos indicus dan Bos taurus dalam Pemeliharaan Tradisional. Proseding Seminar Nasional Peternakan dan Veteriner. Jilid 1, hal. 200-207. 